\begin{tabular}{|l} 
JOURNAL OF EMPOWERMENT \\
Vol. 1, No. 2, December 2017, h. 139-152 \\
ISSN 2580-0620 (Print) \\
ISSN 2597-9809 (online) \\
Available Online at https://jurnal.unsur.ac.id/index.php/JE \\
\hline \hline
\end{tabular}

\title{
HARTA PASCA KEMATIAN SESEORANG (SOSIALISASI HUKUM WARIS ISLAM)
}

\author{
Cucu Solihah \\ Fakultas Hukum Universitas Suryakancana \\ E-mail: cucusolihah2012@gmail.com
}

\begin{tabular}{|l|l|l} 
Masuk : September 2017 & Penerimaan : Oktober 2017 & Publikasi : Desember 2017
\end{tabular}

\begin{abstract}
ABSTAK
Ketentuan harta dan peralihan harta dari pemilik harta (pewaris) kepada para ahli waris berlaku secara otomatis pasca kematian seseorang. Berlaku secara otomatis memberi arti bahwa pihak Pewaris tidak berhak mengatur harta pasca kematiannya demikian pula ahli waris tidak dapat menolak peralihan harta tersebut. Tujuan ditetapkannya ketentuan hukum waris dalam ajaran Islam tidak terlepas dari 5 tujuan hukum (maqodis syariah) yakni dalam rangka memelihara agama, jiwa, harta, keturunan, dan akal, selain itu terdapat keutamaan ketentuan hukum waris telah digariskan dalam ajaran Islam dengan lengkap dan sempurna, karena hakikat harta dalam Islam mutlak menjadi milik sang Tuhan semesta alam, sehingga sangat wajar Tuhanpun mempunyai aturan mengenai apa saja ruang lingkup harta waris, kepada siapa harta itu diberikan, berapa harta yang harus diberikan kepada masing-masing ahli waris, kapasitas manusia hanya menerima amanah atas harta yang dititipkan kepada manusia.Terdapat ketentuan asas waris Islam yakni asas ijbari, bilateral, individual, keadilan berimbang,dan semata akibat kematian.
\end{abstract}

Kata Kunci : Harta, Warisan, Asas.

\begin{abstract}
The provisions of the transition property and property of the owner of the treasure (heir) to the heirs apply automatically post the death of someone. Applies automatically give the sense that the Successor is not entitled to set the property of post death similarly heirs can't resist the transition the treasure. The purpose of the establishment of the provisions of the law of inheritance in Islam is inseparable from the 5 goals of the law (Sharia maqodis) i.e. in order to nourish the soul, religion, property, offspring, and reason, besides there is the virtue of the provisions of the law of inheritance was outlined in the Islamic teachings with the complete and perfect, because of the nature of property in Islam absolutely belongs to the Lord of hosts, so that very reasonable Tuhanpun have rules on what the scope of the estate, to whom property is given, how many treasures that should be given to each of the heirs of human capacity, only accepting the mandate over the treasure that is deposited to the mankind. There are basic provisions of Islamic inheritance IE ijbari, bilateral basis, individual, fairness, balanced, and is solely a result of the death.
\end{abstract}

Keywords: Property, Inheritance, Basis. 


\section{A. Pendahuluan}

\section{Latar Belakang}

Pembagian dan peralihan harta dari pemilik harta (pewaris) kepada para (ahli waris) merupakan bagian dari ketentuan syariat Islam yang wajib dilaksanakan oleh segenap masyarakat muslim, termasuk masyarakat muslim Indonesia. Secara konstitusi pelaksanaan hukum waris Islam tidak melanggar aturan hukum yang berlaku di Indonesia, karena hukum Islam sudah menjadi bagian dari hukum positif, dalam arti hukum yang berlaku dan diberlakukan di masyarakat.

Berkaitan dengan dasar konstitusi, UUD 1945 telah menjamin kebebasan beragama dan melaksanakan kewajiban agama sebagaimana ketentuan Pasal 29 UUD 1945, terlebih dengan ditempatkannya Piagam Jakarta dalam Dekrit Presiden memberi arti secara positif dan bermakna bagi pemeluk-pemeluk yang beragama Islam diwajibkan menjalankan syariat Islam. ${ }^{1}$

Peralihan harta kepada para ahli waris akan berdampak pada kesejahteraan ahli waris dalam hal materi, dan hal tersebut syah-syah saja selama memperolehnya dilakukan secara halal dan dibenarkan berdasarkan hukum, terlebih secara filosofi kesejahteraan adalah juga menjadi tujaun dari konstitusi yakni untuk kesejahteraan umum, dengan demikian setiap warga Negara mempunyai hak untuk mendapatkan penghidupan yang

\footnotetext{
Mara Sutan Rambe, Proses akomodasi hukum Islam ke dalam hukum pidana, Jurnal Cita hukum Fakultas syariah dan hukum UIN Syarif Hidyatulloh Jakarta, Volume. 3 Nomor. 2 Desember 2015, hlm.227
}

layak baik secara materil maupun spiritual. ${ }^{2}$

Harta bagi sebagian orang menjadi sesuatu yang sangat berharga, sehingga manusia rela mengorbankan jiwa dan raganya hanya untuk mengumpulkan harta, namun tidak sedikit pula manusia yang menganggap bahwa harta hanyalah alat/sarana bekal untuk beribadah kepada-Nya, karena pada hakikatnya harta yang dimiliki oleh seseorang merupakan rijki dari Allah yang merupakan amanah/ titipan yang harus dijaga dan dipelihara supaya tidak menjerumuskan si pemilik harta menjadi penghuni neraka.

Perspektif Islam memandang harta dengan acuan akidah yang disarankan Al-Qur'an, yakni dipertimbangkannya kesejahteraan manusia, alam, masyarakat dan hak milik. Pandangan demikian, bermula dari landasan iman kepada Allah, dan bahwa Dia-lah pengatur segala hal dan kuasa atas segalanya. Manusia sebagai makhluk ciptaanNya karena hikmah Ilahiah. Hubungan manusia dengan lingkungannya diikat oleh berbagai kewajiban, sekaligus manusia juga mendapatkan berbagai hak secara adil dan seimbang. Kalau harta seluruhnya adalah milik Allah, maka tangan manusia hanyalah tangan suruhan untuk jadi khalifah. Maksudnya manusia adalah khalifahkhalifah Allah dalam mempergunakan dan mengatur harta itu.

Mufidah, Sistem Hirarki Kelembagaan Badan Pengelola Zakat Zakat Di Indonesia (Tinjuan Pelaksanaan Undang-Undang No. 23 Tahun 2011), Jurnal Cita Hukum Fakultas Syariah dan hukum UIN Syarif Hidyatulloh Jakarta, Volume. 4, Nomor. 2, Desember 2016, hlm.327. 
Ada tiga asas pokok tentang harta dalam ekonomi Islam, yaitu:

a. Allah Maha Pencipta, bahwa manusia yakin semua yang ada di bumi dan di langit adalah ciptaan Allah.

b. Semua harta adalah milik Allah. Manusia hanya memperoleh titipan dan hak pakai saja. Semuanya nanti akan ditinggalkan.

c. Iman kepada hari Akhir. Hari Akhir adalah hari perhitungan, hari pembalasan terhadap dosa dan pahala selama mengurus harta di dunia ini, dan akan ditanya darimana harta diperoleh dan untuk apa didigunakan, semua harus dipertanggungjawabkan. ${ }^{3}$

Berdasarkan nilai dan esensi harta sebagaimana tersebut di atas, maka dalam keadaan si pemilik harta meninggal, berlakulah hukum kewarisan yang merupakan salah satu mekanisme peralihan hak kepemilikan atas suatu harta benda. ${ }^{4}$ Lebih lanjut ketentuan Pasal 171 huruf e Intruksi Presiden Nomor 1 Tahun 1991 tentang Kompilasi Hukum Islam menjelaskan bahwa makna harta warisan adalah sebagai harta bawaan ditambah bagian dari harta bersama setelah digunakan untuk keperluan pewaris selama sakit sampai meninggal dunia dan membayar seluruh hutang-hutangnya. Istilah "harta peninggalan" lebih berorientasi kepada harta benda yang dimiliki seseorang semasa hidupnya yang masih tergabung dan

Hendro Wibowo, Harta dalam Perspektif Islam,

http: / / hndwibowo.blogspot.co.id/2008/06/hart a-dalam-perspektif-islam.html, diakses pada tanggal 10 Januari 2017.

4 Rosdinar Sembiring, (2016) Hukum Keluarga Harta-Harta Benda Dalam Perkawinan, Jakarta, Rajawali Press, hlm. 99. belum terpisah antara harta bawaan pewaris dan harta bersama dengan pasangan yang hidup terlama, utang-utang keluarga, wasiat dan biaya-biaya kepengurusan jenajah. ${ }^{5}$ Sehubungan dengan konsep tersebut di atas, maka ajaran agama Islam memiliki konsep yang jelas berkaitan dengan peralihan harta dari si pemilik harta kepada para ahli warisnya dengan suatu kemanisme dan aturan hukum yang jelas, sistematis dan lengkap.

Hukum waris dalam ajaran Islam disebut dengan istilah "faraid" yang merupakan bentuk jamak dari faridah yang berasal dari kata fardu yang mempunyai arti ketetapan, pemberian (sedekah). 6

Waris dalam bahasa Indonesia disebut pusaka, yaitu harta benda dan hak yang ditinggalkan oleh orang yang mati untuk dibagikan kepada yang berhak menerimanya. Pembagian itu lazim disebut Faraidh, artinya menurut syara' ialah pembagian pusaka bagi yang berhak menerimanya. ${ }^{7}$ Sementara Menurut Syamsul Rijal Hamid bahwa pengertian warisan adalah berpindahnya hak dan kewajiban atas segala sesuatu baik harta maupun tanggungan dari orang yang telah meninggal dunia kepada keluarganya yang masih hidup. ${ }^{8}$

Masalah harta pusaka sering menjadi sumber sengketa keluarga, terutama pemicu konflik terjadi

\footnotetext{
H.M. Anshary, (2013), Hukum Kewarisan Islam Dalam Teori Dan Praktik, Yogyakarta, Pustaka Pelajar, hlm.11.

6 Louis Makluf, dalam Amin Husein Nasution, (2012), Hukum Kewarisan Suatu Analisis Komparatif Pemikiran Muhtahid Dan Kompilasi Hukum Islam, Rajawali Press, Jakarta, hlm.49.

Moh Rifai, (1978), Ilmu Fiqih Islam, Semarang, CV Toha Putra, hlm. 513.

8 Syamsul Rijal Hamid, (2011), Buku Pintar Agama Islam, Bogor, Cahaya Salam, hlm. 366.
} 
dalam hal menentukan siapa-siapa yang berhak dan tidak berhak mendapat warisan yang pada gilirannya akan menimbulkan keretakan keluarga. ${ }^{9}$ Dalam kondisi lain terkadang masalah juga timbul dari kesalahpahaman dalam memahami hukum waris islam tidak berpihak kepada kaum perempuan dan melebihkan hak kaum laki-laki, selanjutnya berkaitan dengan bagian masing-masing ahli waris, karena itu Islam datang membawa ketentuan dari Allah SWT, dalam hal waris mewarisi ini secara lengkap dan sempurna dan kewajiban umat islam adalah melaksanakan ketentuan sebagaimana telah digariskan ajaran Islam atas harta dan perpindahan harta dari seorang pewaris kepada para ahli warisnya.

Pada kehidupan masyarakat muslim dewasa ini terjadi fenomena ketidakfahaman hakikat harta khususnya harta yang ditinggalkan oleh pewaris yang harus beralih kepemilikannya kepada para ahli waris, atau dapat pula diketemukan suatu keadaan dimana masyarakat mengalami penurunan pemahaman terhadap ilmu hukum waris Islam, atau ilmu figh mawaris dengan suatu anggapan hukum waris Islam tidak mengikat wajib untuk dilaksanakan, sehingga masyarakat cenderung menyelesaikan sengketa warisnya ke pengadilan negeri atau melalui muswarah keluarga.

Berdasarkan latar belakang tersebut, perlu kiranya dilakukan sosialisasi hukum waris Islam kepada masyarakat, mengingat tanggung jawab mempelajari hukum waris ini menjadi fardu kifayah, sehingga

9 Amin Husein Nasution, (2012) Hukum Kewarisan Suatu Analisis Komparatif Pemikiran Mujtahid Dan Kompilasi Hukum Islam, Jakarta, Rajawali Press, hlm. 52. dituntut ada orang/sekelompok orang yang menyampaikan aturan hukum tersebut sampai terpenuhinya kebutuhan hukum masyarakat terhadap ketentuan waris tersebut sehingga terbebas dosa kaum muslimin atas kewajiban mempelajari ilmu faroid.

\section{Lokasi Pengabdian}

Pengabdian mengenai sosialisasi hukum waris Islam ini dilaksanakan di Mesjid Riyadhussolihin Komplek Gria Maleber Indah Karangtengah Cianjur, yang dilaksanakan 2 hari yakni pada hari/tanggal : Jumat/3 Februari 2017 dan hari/tanggal : Minggu, 5 Februari 2017.

\section{Peserta}

Peserta sosialisasi hukum waris Islam ini dilaksanakan di Mesjid Riyadhussolihin Komplek Gria Maleber Indah Karangtengah Cianjur dihadiri oleh tokoh agama, tokoh masyarakat, jamaah mesjid di lingkungan Kecamatan Karangtengah Cianjur berjumlah 53 (lima puluh tiga) orang.

\section{B. METODE}

Metode yang digunakan dalam pengabdian ini adalah dengan metode kualitatif. metode kualitatif yang dipilih adalah implementasi ketentuan hokum waris Islam di masyarakat Desa Maleber Kecamatan Karangtengah Cianjur karena peneliti mengumpulkan sejumlah informasi secara mendalam pada kasus atau proses atau gejala yang terkait dengan kegiatan sosialisasi hukum waris Islam di kalangan masyarakat komplek perumahan. 10

10 Miles B. Matthew, Huberman, A Michael (2006) Qualitatif data analisys, a sourebook of 


\section{PEMBAHASAN}

Adanya bagian dari hukum Islam yang mengatur mengenai perpindahan harta yang dimiliki seseorang pasca meninggalnya kepada para ahli warisnya merupakan bentuk kasih sayang Allah kepada manusia, karena dengan hukum-Nya, Allah SWT menghendaki terciptanya kedamaian, kerukunan diantara sesama ahli waris.

Sebelum mengkaji lebih lanjut mengenai perpindahan harta dari pewaris kepada ahli waris, pelu dipahami dahulu sumber harta yang menjadi objek waris. Pada umumnya, harta waris bersumber dari harta asal dan harta bersama. Harta bersama dalam kehidupan manusia, tidak dapat dilepaskan dengan hubungan perkawinan antara suami dan istri dalam rumah tangga. Penyebutan harta bersama sebagai terminologi harta yang diperoleh selama perkawinan terasa terlalu global dan bersifat umum, sehingga Pasal $91 \mathrm{KHI}$ lebih merinci objek yang termasuk harta bersama. Rincian ini muncul seiring dengan perkembangan ilmu pengetahuan dan teknologi yang memasukkan hak dan kewajiban sebagai bagian benda tak berwujud ke dalam harta bersama. ${ }^{11}$

Sementara harta asal merupakan harta yang dimiliki masing-masing pasangan suami isteri sebelum pernikahan atau selama pernikahan

new methods, California, SAGE Publication inc, hlm. 169-173.

11 Arso, Hak Atas Kekayaan Intelektual (Haki) Sebagai Harta Bersama Perspektif Kompilasi Hukum Islam. Al-Daulah. Jurnal Hukum Dan Perundangan Islam, Prodi Siyasah Jinayah Fakultas Syari'ah dan Hukum UIN Sunan Ampel Surabaya, Volume. 7. Nomor. 1. April 2017, hlm. 32. dengan kepemilikan individu. Definisi lainnya Harta asal adalah harta yang diperoleh sebelum dan/atau selama perkawinan yang dibawa masuk oleh suami atau oleh isteri yang berasal dari warisan. Adakalanya harta yang diperoleh oleh suami atau isteri sebelum perkawinan bukan dari warisan juga dimasukkan sebagai harta asal. ${ }^{12}$

Perspektif lain memberikan pemahaman bahwa harta dalam suatu perkawinan, yang akan menjadi harta warisan dapat bersumber dari 2 (dua) yakni harta asal dan harta bersama. Harta asal dapat berupa :

1. Harta yang diperoleh pewaris sebelum menikah;

2. Harta yang diperoleh pewaris dalam bentuk hibah, yang diperoleh sebelum atau setelah pernikahan;

Sementara harta bersama atau harta kekayaan dalam perkawinan adalah harta yang diperoleh baik oleh sendiri-sendiri (masing-masing suami/isteri) atau secara bersamasama suami-isteri selama dalam ikatan perkawinan berlangsung tanpa mempersoalkan terdaftar atas nama siapa. ${ }^{13}$

Dalam ajaran Islam setiap harta baik yang harta bersifat kebendaan atau hak disebut dengan tirkah, namun demikian tidak secara otomatis tirkah ini menjadi harta yang akan menjadi hak para ahli waris. Menurut Ibnu Hazm, tidak semua hak milik menjadi

12 Anton Budiarto, Hukum Waris Adat, diakses pada laman https://antonbudiarto.files.wordpress.com/ 2010/10/1-pengertian.ppt, diunduh tanggal 4 Desember 2017.

13 Pasal 1 huruf f kompilasi hokum Islam, dan Pasal 35 Undang-Undang No. 1 Tahun 1974 Tentang Perkawinan. Mendefinisikan harta bersama adalah harta benda yang diperoleh selama perkawinan. 
harta warisan, tetapi hanya terbatas pada hak terhadap harta bendanya, sedangkan menurut ulama Malikiyah, Syafi'iyah dan Hanabilah, semua hak baik bersifat kebendaan atau bukan termasuk harta warisan. ${ }^{14}$.

Harta warisan ialah hak milik seseorang yang meninggal dunia, yang dapat dimanfaatkan secara bebas (tasaruf) semasa hidupnya, setelah dikurangi biaya pengurusan jenazah, utang dan pembayaran wasiat. Lebih lanjut ketentuan Pasal 171 ayat e Kompilasi Hukum Islam menyebutkan bahwa yang dimaksud dengan harta warisan adalah harta bawaan ditambah bagian dari harta bersama setelah digunakan untuk keperluan pewaris (orang yang meninggal) selama sakit sampai meninggalnya, biaya pengurusan jenazah (tajhid), pembayaran utang, dan pemberian untuk kerabat.

Berkenaan dengan pembagian benda, Pasal 91 ayat (1) Kompilasi Hukum Islam (KHI.) membagi harta bersama kepada benda berwujud (lichamelijk zaak) dan benda tidak berwujud (onlichamelijk zaak). Dalam Pasal 91 ayat (2) disebutkan bahwa harta bersama yang berwujud dapat meliputi benda tidak bergerak, bendabergerak dan surat-surat erharga. Kemudian dalam Pasal 91 ayat (3) lebih lanjut disebutkan bahwa harta bersama yang tidak berwujud dapat berupa hak maupun kewajiban.

Adanya bagian dari hukum Islam yang mengatur mengenai perpindahan harta yang dimiliki seseorang pasca meninggalnya kepada para ahli warisnya merupakan bentuk kasih sayang Allah kepada manusia, karena

14 Sayyid Sabiq, (1994), fikih Sunnah jilid 3, Jakata, Pena Pundi Aksara, hlm. 202. dengan hukum-Nya, Allah SWT menghendaki terciptanya kedamaian, kerukunan diantara sesama ahli waris.

Hukum waris Islam mengelompokkan ahli waris menjadi 2 (dua) macam:

1. Ahli waris nasabiyah yaitu ahli waris yang hubungan kewarisannya didasarkan karena adanya hubungan darah (kekerabatan). Kelompok ini dibedakan menjadi dua yaitu dari pihak laki-laki terdiri dari ayah, anak laki-laki, saudara laki-laki, paman dan kakek. Dari pihak perempuan terdiri dari ibu, anak perempuan, saudara perempuan dan nenek.

2. Ahli waris sababiyah yaitu ahli waris yang hubungan kewarisannya karena suatu sebab, yaitu sebab perkawinan dan memerdekakan budak (memerdekan budak saat ini sudah tidak dijumpai lagi). ${ }^{15}$

Dilihat dari bagian yang akan diterima, atau berhak dan tidaknya seseorang menerima warisan, ahli waris dibedakan menjadi 3 (tiga) macam:

1. Ahli waris ashab al-furud yaitu ahli waris yang telah ditentukan bagianbagiannya, seperti $1 / 2$, $1 / 3$, dan lain-lain;

2. Ahli waris ashab al-'usubah yaitu ahli waris yang ketentuan bagiannya adalah menerima sisa setelah diberikan kepada ashab al-furud, seperti anak laki-laki, ayah, paman, dan lain sebagainya;

3. Ahli waris zawi al-arham yaitu orang yang sebenarnya mempunyai hubungan darah

15 Abd Halim, Kedudukan Janda Dalam Hukum Waris Adat, Perdata, Dan Islam: Kajian Integratif, Al-Mazahib, Volume. 5, Nomor. 2, Edisi Desember 2017, hlm. 189. 
dengan sipewaris, namun karena dalam ketentuan nas tidak diberi bagian, maka mereka tidak berhak menerima bagian kecuali apabila ahli waris ashab al-furud dan ashab al-usubah tidak ada. ${ }^{16}$ Ketentuan hukum waris Islam, syarat dengan kesempurnaan aturannya, dari mulai alasan penentuan hukumnya yang sangat logis/masuk akal, juga menyangkut hal-hal teknis perhitungannya, kepada siapa saja harta waris itu berpindah, berapa jumlah perpindahan hartanya semuanya disajikan dalam ketentuan fiqh mawaris.

\section{Dasar Hukum Waris}

Sebagai ketentuan hukum yang bersifat wajib, maka dasar hukum perintah waris tidak hanya al-qur'an juga hadist-hadist nabi yang berfungsi sebagai penjelas ketentuan dari al-qur'an. Berikut ini beberapa dasar perintah hukum waris Islam, sebagaimana firman-Nya QS. AlAnfal : 72, yang artinya :

"Sesungguhnya orang-orang yang beriman dan berhijrah serta beriihad dengan harta dan jiwanya pada jalan Allah dan orang-orang yang memberikan tempat kediaman dan pertolongan (kepada orangorang Muhajirin), mereka itu satu sama lain lindung-melindungi dan (terhadap) orang-orang yang beriman, tetapi belum berhijrah, Maka tidak ada kewajiban sedikitpun atasmu melindungi mereka, sebelum mereka berhijrah. (akan tetapi) jika mereka meminta pertolongan kepadamu dalam (urusan pembelaan) agama, maka kamu wajib memberikan pertolongan kecuali terhadap

Abd Halim, Kedudukan ... Ibid, hlm. 189. kaum yang telah ada perianjian antara kamu dengan mereka. dan Allah Maha melihat apa yang kamu kerjakan".

Demikian pula mengenai ketentuan bahwa kaum wanita juga berhak atas harta waris dari pewaris, sebagaimana QS. An-Nisa ayat 7, yang berbunyi :

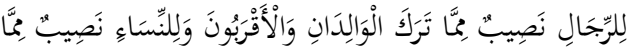

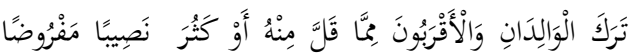

$$
\begin{aligned}
& \text { p: }
\end{aligned}
$$

Sebagai dasar hukum dari hadist, dapat diketahui dari :

Ibnu Mas'ud Radhiyallahuanhu berkata bahwa Rasulullah SAW menetapkan bagi anak tunggal perempuan setengah bagian, dan buat anak perempuan dari anak laki seperenam bagian sebagai penyempurnaan dari $2 / 3$. Dan yang tersisa buat saudara perempuan. (HR. Jamaah kecuali Muslim dan Nasai).

Selain itu juga Pedoman pelaksanaan hukum waris Islam menurut litihad adalah : Masalahmasalah yang menyangkut warisan ada yang sudah dijelaskan permasalahannya dalam Al-Qur'an atau Sunnah dengan keterangan yang kongkret, sehingga tidak timbul macam-macam interpretasi, bahkan mencapai iima' (konsensus) di kalangan ulama dan umat Islam. Selain dari itu masih banyak masalah 
warisan yang dipersoalkan atau diperselisihkan. ${ }^{17}$

\section{Kewajiban Melaksanakan Ketentuan Waris Bagi Muslim}

Adapun suatu kewajiban melaksanakan ketentuan waris bagi muslim, sebagaimana Allah menetapkan setiap aturan untuk ditaati dan dilaksanakan, karena pada setiap hukum syariat terkandung tujuan yang sangat baik bagi manusia, termasuk dalam hal ketaatan untuk melaksanakan ketentuan hukum waris bagi seorang muslim, tanpa kecuali sehingga tidak alasan untuk tidak mentaati setiap aturanNya. Ketegasan akan tuntutan taat dan patuh pada syariah, ditegaskan dalam QS. An-Nisa: 14,

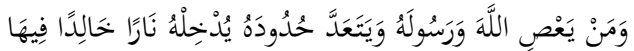

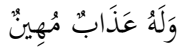

Artinya : Dan barangsiapa yang mendurhakai Allah dan RasulNya dan melanggar ketentuanketentuan-Nya, niscaya Allah memasukkannya ke dalam api neraka sedang ia kekal di dalamnya; dan baginya siksa yang menghinakan.

Bahkan terdapat 3 ayat dalam QS Al-Ma'idah: 44,45 dan 47 yang memberi sebagai peringatan sekaligus ancaman bagi manusia yang tidak mau melaksanakan ketentuan syariah, sebagaimana ayat berikut ini :

Ayat 44 :

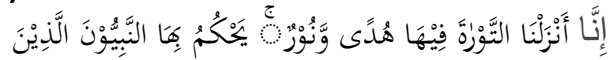

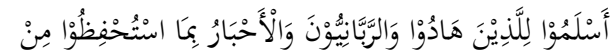

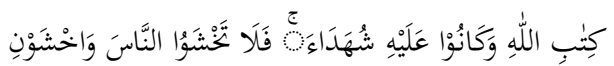

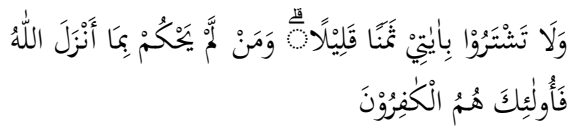

Artinya : Sungguh, Kami yang menurunkan Kitab Taurat; di dalamnya (ada) petunjuk dan cahaya. Yang dengan Kitab itu para nabi yang berserah diri kepada Allah memberi putusan atas perkara orang Yahudi, demikian juga para ulama dan pendeta-pendeta mereka, sebab mereka diperintahkan memelihara kitab-kitab Allah dan mereka menjadi saksi terhadapnya. Karena itu janganlah takut kepada manusia, (tetapi) takutlah kepada-Ku. Dan janganlah kamu jual ayat-ayat-Ku dengan harga murah. Barang siapa tidak memutuskan dengan apa yang diturunkan Allah, maka mereka itulah orang-orang kafir. (QS.AIMa'idah: 44).

Ayat 45 :

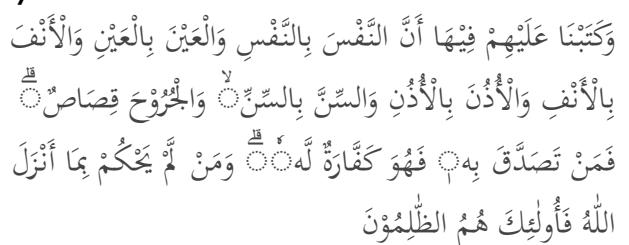

Artinya : Kami telah menetapkan bagi mereka di dalamnya (Taurat) bahwa nyawa (dibalas) dengan nyawa, mata dengan mata, hidung dengan hidung, telinga dengan telinga, gigi dengan gigi, dan luka-luka (pun) ada qisasnya (balasan yang sama). Barang siapa melepaskan (hak qisas)nya, maka itu (menjadi) penebus dosa baginya. Barang siapa tidak memutuskan perkara menurut apa yang diturunkan Allah, 
maka mereka itulah orang-orang zalim. (QS.Al-ma'idah: 45).

Ayat 47:

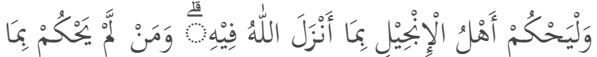

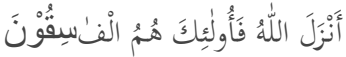

Artinya : Barangsiapa tidak memutuskan perkara menurut apa yang diturunkan Allah, maka mereka itu adalah orangorang yang fasik.

\section{Asas-Asas Kewarisan Islam}

Sebelum mengkaji lebih jauh berkaitan dengan teknis perhitungan dan pembangian waris, maka pemahaman mengenai asas kewarisan Islam menjadi penting/ menjadi prasyarat memahami hukum waris Islam adalah memahami dan mempelajari asas-asas hukum waris Islamnya. Berikut akan dikemukakan asas-asas kewarisan sebagaimana termaksud.

Sebagai hukum yang bersumber dari Al-Qur'an dan Hadist, hukum kewarisan Islam mengandung asasasas yang dalam beberapa hal berlaku pula dalam hukum kewarisan yang bersumber pada sistem non Islam (Barat dan adat) dan dalam hal tertentu mempunyai corak tersendiri berbeda dengan hukum kewarisan pada sistem yang lain.

Setelah digali dari sumber hukumnya, hukum waris Islam mengandung 5 (lima) asas, yakni: asas libari, asas Bilateral, asas individual, asas keadilan berimbang dan asas kewarisan semata akibat kematian. ${ }^{18}$

18 Muhammad Daud Ali, (1991), Hukum Islam Pengantar Ilmu Hukum Dan Tata Hukum Islam di Indonesia, Jakarta, Raja Grafindo Persada, hlm. 322-330.

\section{Asas libari}

Dalam hukum Islam peralihan harta yang telah meninggal kepada yang masih hidup berlaku dengan sendirinya, yang dalam pengertian hukum Islam berlaku secara ijbari/ketentuan yang sifatnya memaksa/melaksanakan kehendak di luar kemampuan sendiri. Artinya peralihan harta tersebut adalah kehendak Allah SWT tanpa tergantung kepada kehendak pewaris atau ahli waris termasuk dalam jumlah yang akan diterimanya.

Dilihat dari segi pewaris (sebelum meninggal), ia tidak dapat menolak peralihan hartanya kepada orang lain (ahli waris) termasuk dalam jumlah peralihan hartanya, sehingga pewaris tidak perlu merencanakan dan memikirkan hartanya sebelum meninggal, karena dengan kematiannya secara otomatis hartanya akan beralih.

Dilihat dari segi pewaris (sebelum meninggal), ia tidak dapat menolak peralihan hartanya kepada orang lain (ahli waris) termasuk dalam jumlah peralihan hartanya, sehingga pewaris tidak perlu merencanakan dan memikirkan hartanya sebelum meninggal, karena dengan kematiannya secara otomatis hartanya akan beralih.

Secara etimologis, faraidh diambil dari kata fardh yang berarti taqdir "ketentuan". Dalam istilah syara" bahwa kata fardh adalah bagian yang telah ditentukan bagi ahli waris. ${ }^{19}$

\section{Asas Bilateral}

Dalam hukum kewarisan Islam berarti bahwa seseorang menerima hak kewarisan dari kedua belah pihak

19 Sayyid Sabiq, (2006) Fiqih Sunnah, Jakarta Selatan, Pena Pundi Aksara, hlm.479. 
garis kerabat, yaitu pihak kerabat garis keturunan laki-laki dan pihak kerabat garis keturunan perempuan. Azas ini secara tegas dapat dilihat dari QS. An-Nisa ayat 7, 11, 12, dan 16.

\section{QS. An-Nisa ayat 7}

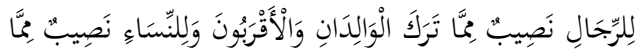

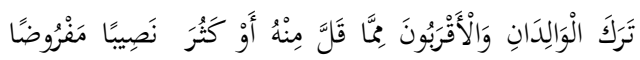
dis:vish

Artinya : Bagi orang laki-laki ada hak bagian dari harta peninggalan ibu-bapa dan kerabatnya, dan bagi orang wanita ada hak bagian (pula) dari harta peninggalan ibubapa dan kerabatnya, baik sedikit atau banyak menurut bahagian yang telah ditetapkan.

QS. An-Nisa ayat 11 , dan ayat 12 yang artinya :

Allah mensyari'atkan bagimu tentang (pembagian pusaka untuk) anak-anakmu. Yaitu : bahagian seorang anak lelaki sama dengan bagahian dua orang anak perempuan dan jika anak itu semuanya perempuan lebih dari dua, Maka bagi mereka dua pertiga dari harta yang ditinggalkan; jika anak perempuan itu seorang saja, Maka ia memperoleh separo harta. dan untuk dua orang ibubapa, bagi masing-masingnya seperenam dari harta yang ditinggalkan, jika yang meninggal itu mempunyai anak; jika orang yang meninggal tidak mempunyai anak dan ia diwarisi oleh ibu-bapanya (saja), Maka ibunya mendapat sepertiga; jika yang meninggal itu mempunyai beberapa saudara, Maka ibunya mendapat seperenam. (Pembagian-pembagian tersebut di atas) sesudah dipenuhi wasiat yang ia buat atau (dan) sesudah dibayar hutangnya. (Tentang) orang tuamu dan anak-anakmu, kamu tidak mengetahui siapa di antara mereka yang lebih dekat (banyak) manfaatnya bagimu. ini adalah ketetapan dari Allah. Sesungguhnya Allah Maha mengetahui lagi Maha Bijaksana.

Ayat 12. Dari surat yang sama:

"Dan bagimu (suami-suami) seperdua dari harta yang ditinggalkan oleh isteri-isterimu, jika mereka tidak mempunyai anak. jika isteri-isterimu itu mempunyai anak, Maka kamu mendapat seperempat dari harta yang ditinggalkannya sesudah dipenuhi wasiat yang mereka buat atau (dan) seduah dibayar hutangnya. Para isteri memperoleh seperempat harta yang kamu tinggalkan jika kamu tidak mempunyai anak. jika kamu mempunyai anak, Maka Para isteri memperoleh seperdelapan dari harta yang kamu tinggalkan sesudah dipenuhi wasiat yang kamu buat atau (dan) sesudah dibayar hutang-hutangmu. jika seseorang mati, baik laki-laki maupun perempuan yang tidak meninggalkan ayah dan tidak meninggalkan anak, tetapi mempunyai seorang saudara laki-laki (seibu saja) atau seorang saudara perempuan (seibu saja), Maka bagi masingmasing dari kedua jenis saudara itu seperenam harta. tetapi jika saudara-saudara seibu itu lebih dari seorang, maka mereka bersekutu dalam yang sepertiga itu, sesudah dipenuhi wasiat yang dibuat olehnya atau 
sesudah dibayar hutangnya dengan tidak memberi mudharat (kepada ahli waris). (Allah menetapkan yang demikian itu sebagai) syari'at yang benarbenar dari Allah, dan Allah Maha mengetahui lagi Maha Penyantun.

Selanjutnya QS. An-Nisa ayat 16 :

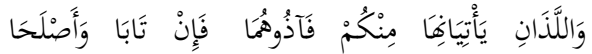

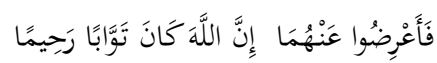

Artinya : dan terhadap dua orang yang melakukan perbuatan keji di antara kamu, Maka berilah hukuman kepada keduanya, kemudian jika keduanya bertaubat dan memperbaiki diri, Maka biarkanlah mereka. Sesungguhnya Allah Maha Penerima taubat lagi Maha Penyayang.

\section{Asas Individual}

Harta kewarisan dapat dibagi-bagi untuk dimiliki secara perorangan, keseluruhan harta warisan dinyatakan dalam nilai tertentu yang mungkin di bagi-bagi kemudian jumlah tersebut dibagikan kepada setiap ahli waris yang berhak menurut kadar bagian masingmasing.

Menghilangkan bentuk individual dengan cara mencampuradukan tanpa perhitungan dan dengan sengaja menjadikan hak-hak kewarisan itu bersifat kolektif, menyalahi ketentuan sebagaimana dikemukakan dalam beberapa ayat al-Qur'an.

\section{Asas Keadilan Berimbang}

Kata adil mempunyai definisi yang berbeda sesuai dengan konteks dan tujuan penggunaannya. Khusus mengenai keadilan dalam kewarisan Islam dapat diartikan dengan keseimbangan antara hak dan kewajiban dan keseimbangan antara yang diperoleh dengan keperluan dan kegunaannya.

Isu yang berkembang akan "ketidak adilan hukum waris Islam" adalah masalah jenis kelamin laki-laki dan perempuan. Islam mempunyai konsep bahwa faktor perbedaan kelamin tidak menentukan dalam hak kewarisan, artinya laki-laki dan perempuan sama-sama mendapat hak kewarisan.

Tentang jumlah bagian yang diperoleh laki-laki dan perempuan, terdapat 3 (tiga) bentuk :

a. Laki-laki mendapat jumlah yang sama dengan perempuan, sebagaimana bagian ibu dan bapak mendapat $1 / 6$ dalam keadaan pewaris meninggakan anak sebagaimana QS. An-Nisa : 11 demikian pula dengan bagian saudara laki-laki dan saudara perempuan sama-sama mendapat $1 / 6$ dalam kasus pewaris kalalah (QS. An-Nisa : 12)

b. Laki-laki mendapat 2 bagian dari anak perempuan QS. AnNisa ayat 11 dan antara saudara laki-laki dan saudara perempuan QS. An-Nisa 16 dan dalam kasus duda mendapat 2 $x$ bagian yang diperoleh janda yakni $1 / 2$ dan $1 / 4$ dalam keadaan pewaris tidak meninggalkan anak atau $1 / 4$ dan $1 / 8$ bila pewaris meninggalkan anak.

c. Laki-laki mendapat 2 bagian dari anak perempuan QS. AnNisa ayat 11 dan antara saudara laki-laki dan saudara perempuan QS. An-Nisa 16 dan dalam kasus duda mendapat 2 $x$ bagian yang diperoleh janda 
yakni $1 / 2$ dan $1 / 4$ dalam keadaan pewaris tidak meninggalkan anak atau $1 / 4$ dan $1 / 8$ bila pewaris meninggalkan anak.

\section{Asas Kematian Semata Akibat Kewarisan}

Hukum Islam menetapkan peralihan harta seseorang berlaku sesudah matinya pewaris Tanpa ada kepastian bahwa pewaris meninggal dunia, warisan tidak boleh dibagibagikan kepada ahli waris. ${ }^{20}$

Pasal $830 \mathrm{KUH}$ Perdata (BW) menyebutkan bahwa pewarisan hanya berlangsung karena kematian, dengan demikian pengertian hukum waris barat menurut KUH Perdata (BW) ialah tanpa adanya orang yang mati dan meninggalkan harta kekayaan, maka tidak ada masalah pewarisan, sehingga harus ada orang yang meninggal dunia, pertama-tama tentulah apa yang dinamakan kematian alami (naturlijke dood). ${ }^{21}$

\section{PENUTUP}

1. Kesimpulan

Asas dalam kajian hukum berasal dari B. Arab, asasun yang artinya dasar, pondasi, basis, dan jika dihubungkan dengan sistem berfikir, yang dimaksud dengan asas adalah landasan berfikir yang sangat mendasar. Jika kata asas

20 A. Rachmad Budiono, (1999), Pembaharuan Hukum Kewarisan Islam di Indonesia, PT.Citra Aditya Bakti, Bandung, hlm. 10.

21 Anita Kamilah dan M. Rendy Aridhayandi, Kajian Terhadap Penyelesaian Sengketa Pembagian Harta Warisan Atas Tanah Akibat Tidak Dilaksanakannya Wasiat Oleh Ahli Waris Dihubungkan Dengan Buku II Kitab Undang-Undang Hukum Perdata Tentang Benda (Van Zaken), Jurnal Wawasan Hukum Sekolah Tinggi Hukum Bandung, Volume. 32, Nomor. 1, Februari 2015, hlm. 24 dihubungkan dengan hukum, yang dimaksud dengan asas adalah kebenaran yang dipergunakan sebagai tumpuan berfikir dan alasan pendapat,terutama dalam penegakan dan pelaksanaan hukum. Asas hukum pada umumnya berfungsi sebagai rujukan untuk mengembalikan segala masalah yang berkenaan dengan hukum.

Berdasarkan hal tersebut, mempelajari dan memahami asas kewarisan merupakan langkah utama dan pertama guna melaksanakan hukum waris Islam di masyarakat yang kesemuanya diambil dari sumber hukum yang bersumber dari al-qur'an dan hadist nabi.

\section{Saran}

Berdasarkan hasil pelaksanaan pengabdian masyarakat yang dilaksanakan di Mesjid Riyadhussolihin Komplek Gria Maleber Indah Karangtengah Cianjur, yang dilaksanakan 2 hari yakni pada hari/ tanggal : Jumat, 3 Februari 2017 dan hari/tanggal : Minggu 5 Februari 2017 diharapkan adanya peningkatan kesadaran masyarakat muslim untuk memahami hakikat harta dan juga hukum waris Islam melalui sosialisasi dan ceramahceramah keagamaan yang dilakukan secara kontinyu, selain itu juga diperluakan panduan diklat hukum waris Islam bagi masyarakat dan yang tidakkalah pentingnya juga adanya lembaga konsultasi hukum Islam di Cianjur.

\section{UCAPAN TERIMA KASIH}

Seiring dengan telah terlaksananya kegiatan sosialisasi hukum waris Islam ini dilaksanakan di Mesjid Riyadhussolihin Komplek Gria Maleber Indah Karangtengah, Cianjur dengan ini kami mengucapkan terimakasih dan 


$$
\begin{aligned}
& \text { penghargaan yang setinggi- } \\
& \text { tingginya kepada : } \\
& \begin{array}{l}
\text { 1. Kepala Desa Maleber } \\
\text { Kecamatan Karangtengah } \\
\text { Cianjur; }
\end{array}
\end{aligned}
$$

\section{DAFTAR PUSTAKA}

\section{A. Buku}

A.Rachmad Budiono, (1999) Pembaharuan Hukum Kewarisan Islam di Indonesia, Bandung, PT.Citra Aditya Bakti.

Amin Husein Nasution, (2012) Hukum Kewarisan Suatu Analisis Komparatif Pemikiran Muitahid Dan Kompilasi Hukum Islam, Jakarta, Rajawali Press.

H.M. Anshary, (2013) Hukum Kewarisan Islam Dalam Teori Dan Praktik, Yogyakarta, Pustaka Pelajar.

Miles B. Matthew, Huberman, A Michael (2006) Qualitatif data analisys, a sourebook of new methods, California, SAGE Publication inc.

Moh Rifai, (1978) Ilmu Fiqih Islam, Semarang, CV Toha Putra.

Muhammad Daud Ali, (1991) Hukum Islam Pengantar Ilmu Hukum

\begin{abstract}
Dan Tata Hukum Islam di Indonesia, Jakarta, RajaGrafindo Persada.
\end{abstract}

Muhammad Jawad Mughniyah, (2000), Fiqih Lima Mazhab, Jakarta, Lentera.

Rosdinar Sembiring, (2016) Hukum Keluarga Harta-Harta Benda Dalam Perkawinan, Jakarta, Rajawali Press.

Sayyid Sabiq, (2006) Fiqih Sunnah, Jakarta Selatan, Pena Pundi Aksara.

Syamsul Rijal Hamid, (2011) Buku Pintar Agama Islam, Bogor, Cahaya Salam.

\section{B. Peraturan Undangan}

Perundang-

Undang-Undang Dasar Negara Republik Indonesia 1945.

Kitab Undang-Undang Hukum Perdata (Burgerlijk Wetboek voor Indonesie).

Undang-Undang Nomor 1 Tahun 1974 Tentang Perkawinan.

Intruksi Presiden Nomor 1 Tahun 1991 Tentang Kompilasi Hukum Islam.

\section{Jurnal}

Abd Halim, Kedudukan Janda Dalam Hukum Waris Adat, Perdata, Dan Islam: Kajian Integratif, AlMazahib, Volume. 5, Nomor. 2, Edisi Desember 2017.

Anita Kamilah dan M. Rendy Aridhayandi, Kajian Terhadap Penyelesaian Sengketa 
Pembagian Harta Warisan Atas Tanah Akibat Tidak Dilaksanakannya Wasiat Oleh Ahli Waris Dihubungkan Dengan Buku II Kitab UndangUndang Hukum Perdata Tentang Benda (Van Zaken), Jurnal Wawasan Hukum Sekolah Tinggi Hukum Bandung, Volume. 32, Nomor. 1, Februari 2015.

Arso, Hak Atas Kekayaan Intelektual (Haki) Sebagai Harta Bersama Perspektif Kompilasi Hukum Islam. Al-Daulah. Jurnal Hukum Dan Perundangan Islam, Prodi Siyasah Jinayah Fakultas Syari'ah dan Hukum UIN Sunan Ampel Surabaya, Volume. 7. Nomor. 1. April 2017.

Mara Sutan Rambe, Proses akomodasi hukum Islam ke dalam hukum pidana, Jurnal Cita hukum Fakultas syariah dan hokum UIN Syarif Hidyatulloh Jakarta, Volume. 3 Nomor. 2 Desember 2015.

Mufidah, Sistem
Kelembagaan $\begin{array}{r}\text { Hirarki } \\ \text { Badan }\end{array}$
Pengelola Zakat Zakat Di
Indonesia (Tinjuan Pelaksanaan
Undang-Undang No. 23 Tahun
2011 ), Jurnal Cita hukum
Fakultas syariah dan hukum UIN
Syarif Hidyatulloh Jakarta,
Volume. 4, Nomor. 2 Desember
2016.

\section{Sumber lain}

Anton Budiarto, Hukum Waris Adat, diakses pada laman https://antonbudiarto.files.wor dpress.com/2010/10/1 -

pengertian.ppt, diunduh tanggal 4 Desember 2017.

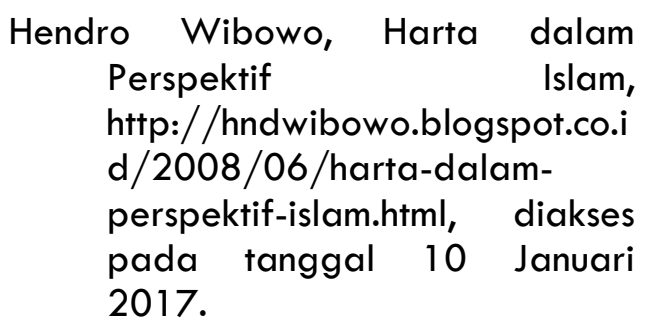

Hendro Wibowo, Harta dalam Perspektif Islam, http://hndwibowo.blogspot.co.i d/2008/06/harta-dalamperspektif-islam.html, diakses pada tanggal 10 Januari 2017. 